\title{
INFLUENCE OF Q.C. PRACTICES IN CEMENT FACTORIES IN SULAIMANI CITY ON PRODUCTIVITY AND PROFITABILITY
}

\author{
Dr. Yassin Mustafa Ahmed \\ Lecturer, Department of Mechanical Engineering/Production Engineering, College of \\ Technique Engineering, Sulaimani Polytechnic University, Iraq
}

\section{Mohammed H. Hassan}

Engineering, Department of Mechanical Engineering/Production Engineering, College of Technique Engineering, Sulaimani Polytechnic University, Iraq

\begin{abstract}
High quality and service is a major purpose of any organizations in order to satisfy their consumers. And quality control can measure the quality of product. In fact, quality control not concern to inspection only, but it related to good technology and proper management all together. Although leadership responsibility is a great matter and needs to pay attention in the firm. Also, a vast majority of quality cost could not be control just by the manager, and cooperative working is required. Productivity and profitability are two major points that is focused on in any production system, and they highly affected by quality control. So that the current research is studying the influence of using of the quality controls program on outputs, and profitability in the cement plants in Sulaimani city. In the study questioner was spread, in it was randomly divided into four of the cement factories (Gasin, Tasluja, Delta, and Bazya) factories. And the collected data is analyzed using SPSS software. The results show that the quality control has a crucial positive influence on both productivity and profitability in the cement factories. Therefore, the factories must focus on the quality control to obtain their objectives which are high production rate and high profit. Although most employers believe that applying the principles of quality control has a significant benefit in increasing productivity and profitability, this is a clear sign of the quality control program's influence. On the other hand, less than half of the respondents believe that using the QC program is useful in cement factories to introduce new ideas and provide training.
\end{abstract}

Keywords: Quality Control; Leadership responsibility; Productivity; Profitability; Cement factories; Sulaimani City; SPSS.

Cite this Article: Yassin Mustafa Ahmed and Mohammed H. Hassan, Influence of Q.C. Practices in Cement Factories in Sulaimani City on Productivity and Profitability, International Journal of Industrial Engineering Research and Development, 10(2), 2019, pp. 1-13.https://iaeme.com/Home/issue/IJIERD?Volume=10\&Issue $=2$ 


\section{INTRODUCTION}

Nowadays the organizations are concentrating on the demand of customers. And to achieve this requirement numerous organizations attempt to gain customer's satisfying by emphasizing products of high quality and services [1]. The measure of the product or service that meets the customer's destination is a quality of product and service [2]. In traditional quality control, the focus was on inspection. The responsibility in quality control just for the department of inspection, and it was paid attention more about the process of manufacturing. While the quality control in the modern point of view the desired quality earned by both good technology and good management. In an organization, the integration of both is needed to obtain a successful quality control system. For management factor, the term" total quality management" is often used. The technology factors cover the traditional statistical tools gathered with up-to-date inspection and measurement methods [3].

The skill of leadership is an important factor to work in a new way, new idea, and innovations [4]. The quality of leadership is a significant factor to improvement the quality in the manufacturing process, product, and services. The method to implement quality in any organization is involving and committing the leadership. Furthermore, quality and speed could prolong organization in a competitive site, and these two points possible to being dependable to success for firms for a long period of time [5]. Evans, shows the $60 \%$ to $90 \%$ of the total costs of quality cannot easily control just by management, but could involvement of the workers to delivering quality, and they can develop the firms across meeting the specifications of both process and product, also it can be achieved the target of the performance. In an organization, the suitable leadership can activate a group of person to show and find inventive ideas which are called "Strong forces", of leaders and could move concentrate from amounts, to quality and velocity [6, 7]. The basic rationale in quality management is that the leaders impact the motivation of an employee's system, and motivated members assist for improving performance of quality [8]. Existing leadership theory has not used either quality improvement or firms' performance as criteria for leadership effectiveness. Incorporating leadership theory into the quality management is a considerable step in integrating quality management with management theory [9].

Often, productivity is the gauge of the output to input rate of fabricating firms. And it is the indicator of the efficiency in the process of the production systems, on the other hands, if a production system is not enough efficient, then lead the firm to financially risk that impact the profitability of the firms. And as is evident, the profitability is a measure of capability for making a profit for an organization [10]. The main goal for any companies from measurement of production is to demonstrate the performance of companies through transformed inputs into outputs (products and services). The simplest productivity measuring types is the output ratio as a particular form of input; such as sales per worker. Classical economics discusses improvements in productivity through capital and labor, where increasing the productivity is an important indicator in fostering the economy [11, 12]. Common kinds of investments that boost productivity include substituting labor capital through process automation, enhancing current technology, and creating contemporary employee training programs.

Productivity can also rely on a number of variables, such as resource allocation quality [13]. Rather than raising real rates of capital or labor investment, resource reallocation can boost productivity through strategic, process, organizational structure, and value changes [15].

The profit measures firms ' economic performance and it is a tiny quantity of cost measure of receipts. Different profit measures include varying ' receipts and expenses ' definitions. In general, economists split the expenses into fixed and variable costs. The fixed costs are those not varying with the output generated, whereas the variable costs differ with production, as their name indicates [15]. More productive firms have a competitive advantage over their less 
productive rivals, and it is significantly affecting the profitability. Firms with higher levels of total factor productivity win greater intakes [16].

The present paper attempts to show the effect of quality control on productivity and profitability in cement factories in Sulaimani City.

\section{LITERATURE REVIEW}

The researchers for a prolonged period of time studied the importance of quality control in any organization and its influence on productivity and profitability. Abdulrahman was studying the effect of quality practices in the dried date industry in Saudi Arabia on productivity and profitability. He was discovered that the biggest variables affecting productivity and profitability were quality measurement, concentrate on employees, benchmarking, training and connections with suppliers [1]. He also showed that a good connection exists between quality management, profitability and productivity, as well as productivity work as intercessors between quality management and profitability. And he proved that ultimately improving productivity and profitability greatly related to a goodness of quality control. Furthermore, the quality also can impact the competitiveness of the firm by focusing all of the members to improving the quality $[1,17]$. Realized that the quality control, good management, and training have an importance and beneficial influence for improving the competitiveness, satisfying the consumer and improvement of company's economy significantly. Milanoi, showed that the successful quality management direct the firm into the required performance, and good quality relate to role of leadership and his responsibility. Jamshed H. Khan researched the impact on productivity in Pakistan's company of total quality management. He asserted that the quality management lead to betterment of all types of performance such as monetary, satisfying the customers, and satisfying the workforce. Also he believed that total quality management "TQM" is a cause of organization to compete in the global market [18]. R. Selladurai, studied the impact of several factors that affect the profitability, productivity, and performance. He proved that the most significant variables to improve an organization is the quality with regard to productivity, profitability, and performance [19]. Deming found that the decrease of cost, errors, remake, retard depend upon the improvement of quality, and it causes increasing of the productivity [20].

\section{METHODOLOGY}

The project methodology established through:

- The questionnaire forms.

- $\quad$ SPSS software.

- Study and investigation the data that collected.

- Final conclusion and reporting the results to local government.

The current study used a survey questionnaire, and the data is analyzed by using SPSS software. The data collected from cement factories in Sulaimani city in Iraq. The questionnaires randomly divided upon of four of the cement plants. And it is consists of a number of questions in Kurdish/English language in order to be understandable for all participants. And our advice for the participants that this questionnaire is optional and voluntary, but your response is crucial for us to improve the study, and improve the educational purposes. 72 of the forms were received out of 85 forms. The most crucial objective of the study that it focused on it, is the influence of quality control in the cement factories on both sectors productivity, and profitability, and the all points in the questions was about the influence of implementation of quality control in the cement factories. 
Sulaimani governorate is placed northeast of the Iraq [21], there are five cement plans which are Bazian, Gasin, Tasluja, Delta, and Mass, the annual production and starting year of operation of the factories are listed in table 1.

Table 1: Annual production rate and starting year of operation of Sulaimani city cement factories [22-25].

\begin{tabular}{ccc}
\hline Cement factory & Annual production rate (million tons) & Operated since \\
\hline Bazian & 2.5 & 2008 \\
\hline Gasin & 1.7 & - \\
\hline Tasluja & 2.3 & 1985 \\
\hline Delta & 2 & 2014 \\
\hline Mass & 6 & 2008 \\
\hline
\end{tabular}

\subsection{Data Analyzing}

In the tables below show the data was obtained by SPSS program and after the distribution of the questionnaire forms to the engineers and departments that associated with the management and quality control sectors.

The information and details include the factors that have been taken into consideration and which clearly indicate the influence of quality control in many aspects in the cement factories such as productivity, profitability, reducing risks and damage, improving communication, solving problems, and many other factors. Table 2 shows the details of the benefits of using the Quality control programs in the firms.

Table 2 The benefits of quality control programs in the firms

\begin{tabular}{lcccc}
\hline \multicolumn{1}{c}{ Grades } & Frequency & Percent & Valid Percent & Cumulative Percent \\
\hline very bad & 4 & 5.6 & 5.6 & 5.6 \\
\hline fair & 7 & 9.7 & 9.9 & 15.5 \\
\hline good & 17 & 23.6 & 23.9 & 39.4 \\
\hline very good & 43 & 59.7 & 60.6 & 100.0 \\
\hline Total & 71 & 98.6 & 100.0 & \\
\hline Missing System & 1 & 1.4 & & \\
\hline Total & 72 & 100.0 & & \\
\hline
\end{tabular}

The effect of quality control programs to reducing risk in the firms are showing in Table 3.

Table 3 Effect of quality control programs to reducing risk in the firms

\begin{tabular}{lcccc}
\hline \multicolumn{1}{c}{ Grades } & Frequency & Percent & Valid Percent & Cumulative Percent \\
\hline very bad & 2 & 2.8 & 2.9 & 2.9 \\
\hline fair & 18 & 25.0 & 26.1 & 29.0 \\
\hline good & 27 & 37.5 & 39.1 & 68.1 \\
\hline very good & 22 & 30.6 & 31.9 & 100.0 \\
\hline Total & 69 & 95.8 & 100.0 & \\
\hline Missing System & 3 & 4.2 & & \\
\hline Total & 72 & 100.0 & & \\
\hline
\end{tabular}

Table 4 shows the influence of using the Quality control programs in the firms in reducing loss of time or inefficient practices. 
Table 4 Influence of using the Quality control programs in the firms in reducing loss of time

\begin{tabular}{lcccc}
\hline \multicolumn{1}{c}{ Grades } & Frequency & Percent & Valid Percent & Cumulative Percent \\
\hline Very Bad & 3 & 4.2 & 4.3 & 4.3 \\
\hline Bad & 8 & 11.1 & 11.4 & 15.7 \\
\hline Fair & 21 & 29.2 & 30.0 & 45.7 \\
\hline Good & 24 & 33.3 & 34.3 & 80.0 \\
\hline Very Good & 14 & 19.4 & 20.0 & 100.0 \\
\hline Total & 70 & 97.2 & 100.0 & \\
\hline Missing System & 2 & 2.8 & & \\
\hline Total & 72 & 100.0 & & \\
\hline
\end{tabular}

Specifics information of Improve the communication between the members in the firm after using quality control programs in table 5

Table 5 The role of quality control programs to improving the communication between the members in the firm

\begin{tabular}{lcccc}
\hline \multicolumn{1}{c}{ Grades } & Frequency & Percent & Valid Percent & Cumulative Percent \\
\hline Very Bad & 5 & 6.9 & 7.1 & 7.1 \\
\hline Bad & 9 & 12.5 & 12.9 & 20.0 \\
\hline Fair & 28 & 38.9 & 40.0 & 60.0 \\
\hline Good & 17 & 23.6 & 24.3 & 84.3 \\
\hline Very Good & 11 & 15.3 & 15.7 & 100.0 \\
\hline Total & 70 & 97.2 & 100.0 & \\
\hline Missing System & 2 & 2.8 & & \\
\hline Total & 72 & 100.0 & & \\
\hline
\end{tabular}

The effect of quality control programs to highlighting and solving the problems are shows in tables 6 , and 7.

Table 6 Highlighting procedural problems

\begin{tabular}{lcccc}
\hline \multicolumn{1}{c}{ Grades } & Frequency & Percent & Valid Percent & Cumulative Percent \\
\hline Very Bad & 8 & 11.1 & 11.6 & 11.6 \\
\hline Bad & 5 & 6.9 & 7.2 & 18.8 \\
\hline Fair & 14 & 19.4 & 20.3 & 39.1 \\
\hline Good & 28 & 38.9 & 40.6 & 79.7 \\
\hline Very Good & 14 & 19.4 & 20.3 & 100.0 \\
\hline Total & 69 & 95.8 & 100.0 & \\
\hline Missing System & 3 & 4.2 & & \\
\hline Total & 72 & 100.0 & & \\
\hline
\end{tabular}

Table 7 Solving problems

\begin{tabular}{lcccc}
\hline \multicolumn{1}{c}{ Grades } & Frequency & Percent & Valid Percent & Cumulative Percent \\
\hline Very Bad & 4 & 5.6 & 5.7 & 5.7 \\
\hline Bad & 9 & 12.5 & 12.9 & 18.6 \\
\hline Fair & 16 & 22.2 & 22.9 & 41.4 \\
\hline Good & 21 & 29.2 & 30.0 & 71.4 \\
\hline Very Good & 20 & 27.8 & 28.6 & 100.0 \\
\hline Total & 70 & 97.2 & 100.0 & \\
\hline Missing System & 2 & 2.8 & & \\
\hline Total & 72 & 100.0 & & \\
\hline
\end{tabular}


Allowing employees to introducing new ideas and practices for developing the company has a wide influence to increasing confidence in the firm, and providing training and supervision for staff in performing their roles, and appreciation the outstanding staff all this details are showing in tables $8,9,10$, and 11 .

Table 8 Confidence in the firm

\begin{tabular}{lcccc}
\hline \multicolumn{1}{c}{ Grades } & Frequency & Percent & Valid Percent & Cumulative Percent \\
\hline Very Bad & 3 & 4.2 & 4.3 & 4.3 \\
\hline Bad & 9 & 12.5 & 13.0 & 17.4 \\
\hline Fair & 14 & 19.4 & 20.3 & 37.7 \\
\hline Good & 19 & 26.4 & 27.5 & 65.2 \\
\hline Very Good & 24 & 33.3 & 34.8 & 100.0 \\
\hline Total & 69 & 95.8 & 100.0 & \\
\hline Missing System & 3 & 4.2 & & \\
\hline Total & 72 & 100.0 & & \\
\hline
\end{tabular}

Table 9 Providing training and supervision for staff in performing their roles.

\begin{tabular}{lcccc}
\hline \multicolumn{1}{c}{ Grades } & Frequency & Percent & Valid Percent & Cumulative Percent \\
\hline Very Bad & 22 & 30.6 & 31.4 & 31.4 \\
\hline Bad & 7 & 9.7 & 10.0 & 41.4 \\
\hline Fair & 14 & 19.4 & 20.0 & 61.4 \\
\hline Good & 13 & 18.1 & 18.6 & 80.0 \\
\hline Very Good & 14 & 19.4 & 20.0 & 100.0 \\
\hline Total & 70 & 97.2 & 100.0 & \\
\hline Missing System & 2 & 2.8 & & \\
\hline Total & 72 & 100.0 & & \\
\hline
\end{tabular}

Table 10 New ideas of employees and practices for developing the company

\begin{tabular}{lcccc}
\hline \multicolumn{1}{c}{ Grades } & Frequency & Percent & Valid Percent & Cumulative Percent \\
\hline very bad & 17 & 23.6 & 23.9 & 23.9 \\
\hline bad & 7 & 9.7 & 9.9 & 33.8 \\
\hline fair & 16 & 22.2 & 22.5 & 56.3 \\
\hline good & 17 & 23.6 & 23.9 & 80.3 \\
\hline very good & 14 & 19.4 & 19.7 & 100.0 \\
\hline Total & 71 & 98.6 & 100.0 & \\
\hline Missing System & 1 & 1.4 & & \\
\hline Total & 72 & 100.0 & & \\
\hline
\end{tabular}

Table 11 The appreciation and rewards

\begin{tabular}{lcccc}
\hline \multicolumn{1}{c}{ Grades } & Frequency & Percent & Valid Percent & Cumulative Percent \\
\hline very bad & 27 & 37.5 & 38.0 & 38.0 \\
\hline bad & 11 & 15.3 & 15.5 & 53.5 \\
\hline fair & 16 & 22.2 & 22.5 & 76.1 \\
\hline good & 9 & 12.5 & 12.7 & 88.7 \\
\hline very good & 8 & 11.1 & 11.3 & 100.0 \\
\hline Total & 71 & 98.6 & 100.0 & \\
\hline Missing System & 1 & 1.4 & & \\
\hline Total & 72 & 100.0 & & \\
\hline
\end{tabular}


Table 12 below display the opinions of employers in cement plant about adopts the collective and cooperative working style.

Table 12 The employers opinions in cement plant about adopts the collective and cooperative working style

\begin{tabular}{lcccc}
\hline \multicolumn{1}{c}{ Grades } & Frequency & Percent & Valid Percent & Cumulative Percent \\
\hline very bad & 7 & 9.7 & 9.9 & 9.9 \\
\hline bad & 9 & 12.5 & 12.7 & 22.5 \\
\hline fair & 22 & 30.6 & 31.0 & 53.5 \\
\hline good & 20 & 27.8 & 28.2 & 81.7 \\
\hline very good & 13 & 18.1 & 18.3 & 100.0 \\
\hline Total & 71 & 98.6 & 100.0 & \\
\hline Missing System & 1 & 1.4 & & \\
\hline Total & 72 & 100.0 & & \\
\hline
\end{tabular}

The effectiveness of quality control programs on productivity and profitability, and his influence to increasing productivity and profitability, and specifics was show in tables 13 , and 14 respectively.

Table 13 Quality control and his effect to increasing productivity

\begin{tabular}{lcccc}
\hline \multicolumn{1}{c}{ Grades } & Frequency & Percent & Valid Percent & Cumulative Percent \\
\hline bad & 10 & 13.9 & 14.1 & 14.1 \\
\hline fair & 18 & 25.0 & 25.4 & 39.4 \\
\hline good & 22 & 30.6 & 31.0 & 70.4 \\
\hline very good & 21 & 29.2 & 29.6 & 100.0 \\
\hline Total & 71 & 98.6 & 100.0 & \\
\hline Missing System & 1 & 1.4 & & \\
\hline Total & 72 & 100.0 & & \\
\hline
\end{tabular}

Table 14 Quality control and his effect to increasing profitability

\begin{tabular}{lcccc}
\hline \multicolumn{1}{c}{ Grades } & Frequency & Percent & Valid Percent & Cumulative Percent \\
\hline Very Bad & 1 & 1.4 & 1.4 & 1.4 \\
\hline Bad & 6 & 8.3 & 8.6 & 10.0 \\
\hline Fair & 20 & 27.8 & 28.6 & 38.6 \\
\hline Good & 19 & 26.4 & 27.1 & 65.7 \\
\hline Very good & 24 & 33.3 & 34.3 & 100.0 \\
\hline Total & 70 & 97.2 & 100.0 & \\
\hline Missing System & 2 & 2.8 & & \\
\hline Total & 72 & 100.0 & & \\
\hline
\end{tabular}

\section{RESULT AND DISCUSSION}

\subsection{Introduction}

The section below describes the results and the influence of quality control programs and enforcement in cement factories in Sulaimani city, and analyses the data that display in previous section, and discuss their impact at many sector in the cement factories, especially their impact on productivity and profitability. 


\subsection{Benefits of Using Quality Control Program in the Firms}

Figure 1 show the benefits of using the Quality control programs in the cement factories. It is found that quality control programs have considerable significance at many sectors in the cement factories. Figure 1 show that more that eighty-four per cent of the workers in these factories believe that the application of quality programs have an important role in the factory.

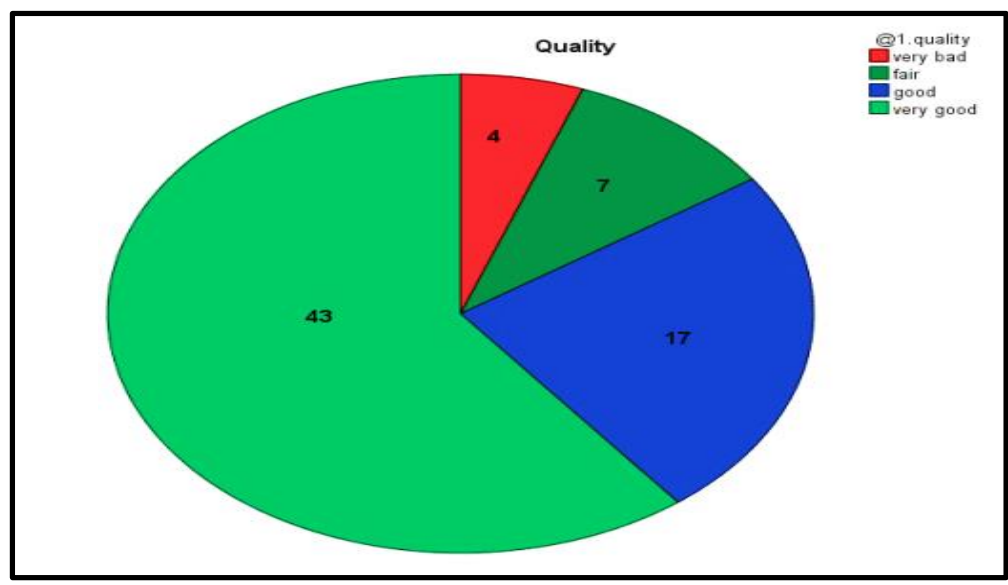

Figure 1 Benefits of using the Quality control programs in the firms

\subsection{Effect of Quality Control Programs to Reducing Risk in the Firms}

Figure 2 show the effect of quality control programs to reducing risk in the firms.

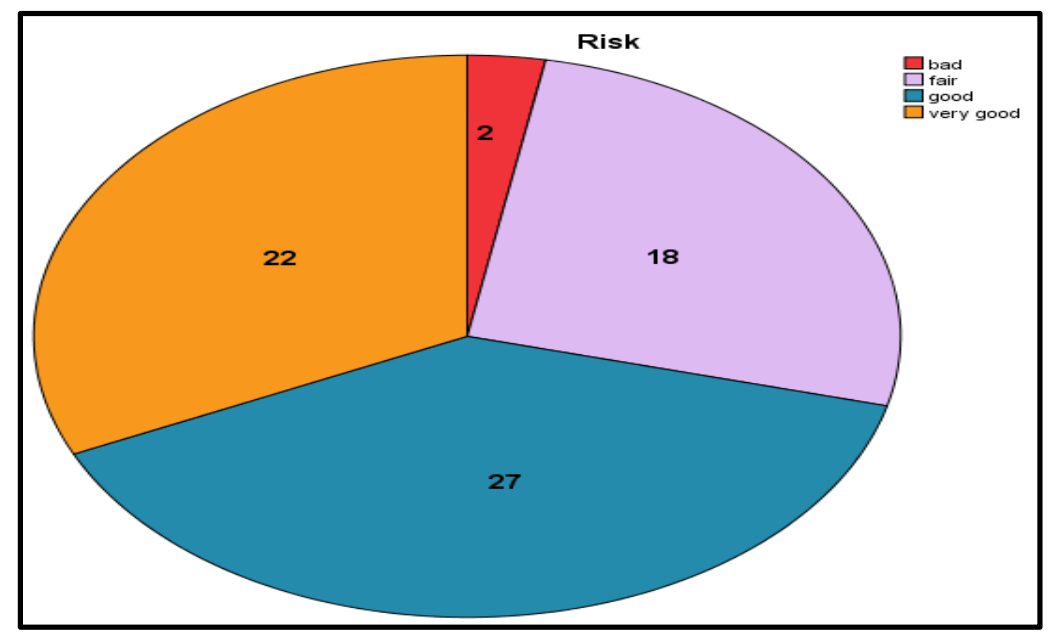

Figure 2 The effect of quality control programs to reducing risk in the firms

The risk in the cement plants came from diffident section or diffident zones. Raw materials risk, furnaces risks, emissions gas, and other health effects. Figure 4.2 show that more than $\% 65$ of the workers in these factories believes that the application of quality programs have an important role to reducing the risk in the factory.

\subsection{Effect of Quality Control Programs in the Firms to Reducing Loss of Time or Inefficient Practices}

Figure 3 shows the influence of quality control programs in the firms to reducing loss of time or inefficient practices. From the table 4.3 we obtained that around 55\% of employing think that the quality control program has an important role to losing time in the cement factories. 


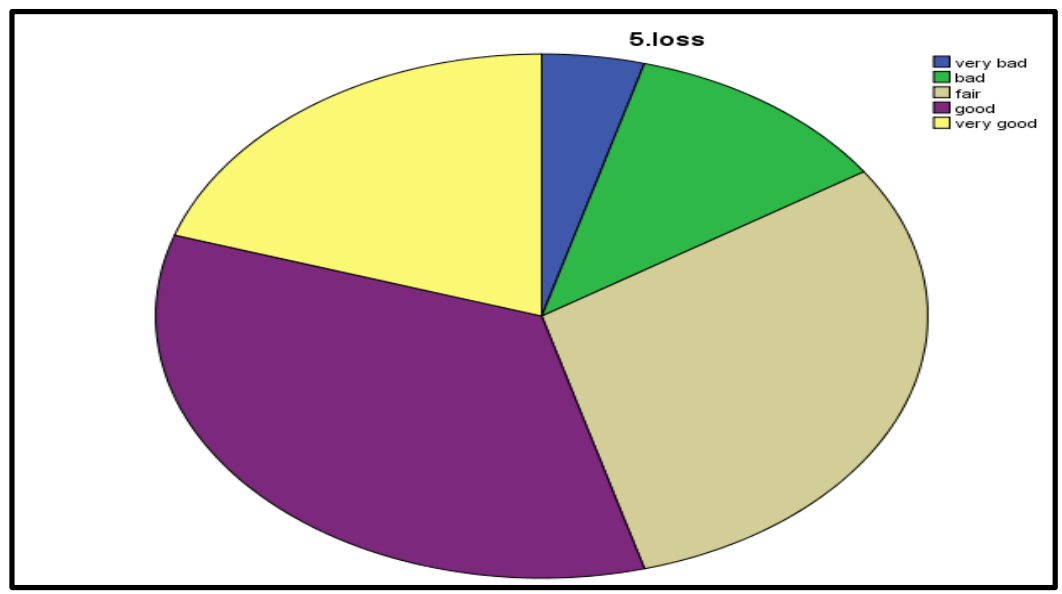

Figure 3 The influence of quality control programs in the firms to reducing loss of time or inefficient practices

\subsection{Effect of Quality Control Programs to Improve the Communication between the Members}

The influence of using of quality control programs to improve the communication between the members in the firm shows in figure 4.

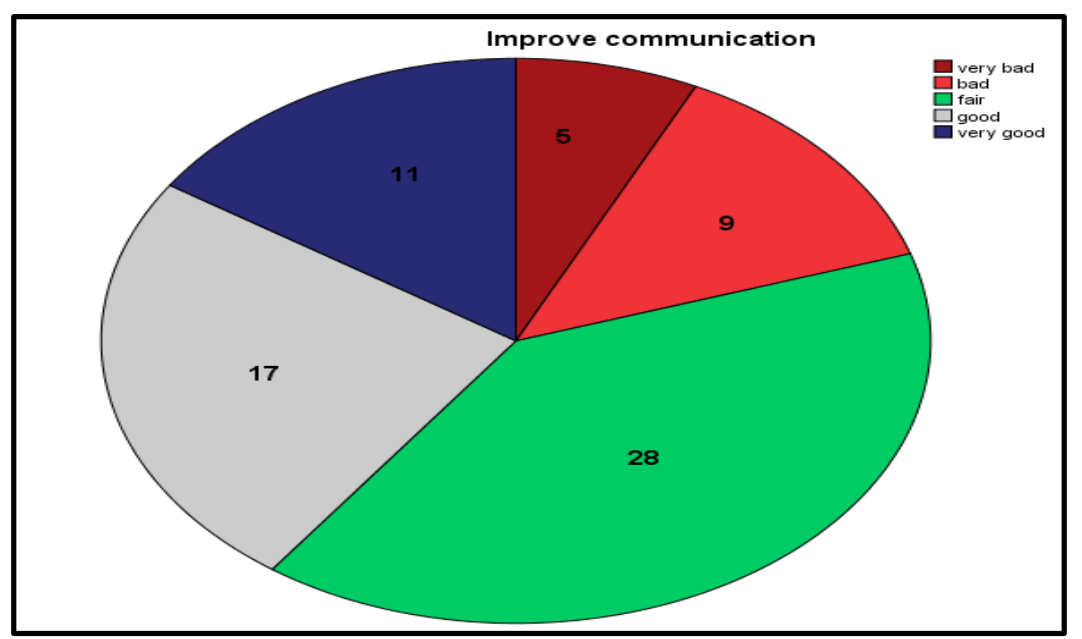

Figure 4 The influence using of quality control programs in the firms to improve the communication between the members

From the figure above we found that forty percent of the employers in the cement factories consider that the quality control program has an improvement impact to improving the communication between the members.

\subsection{Effect of Quality Control Programs in the Firms in Highlighting the Problems and its Role to Solving}

The effect of quality control in the firms in highlighting the problems and its role to solving are showing in figures 5 , and 6 respectively. 


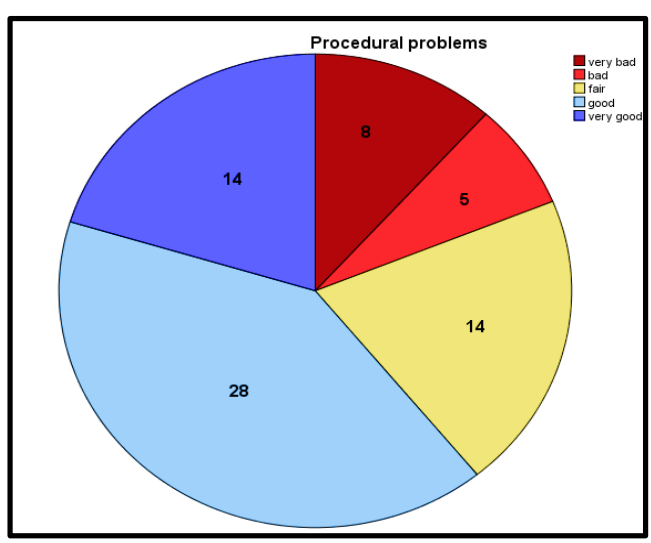

Figure 5 Using quality control programs in the firms to highlighting procedural problems.

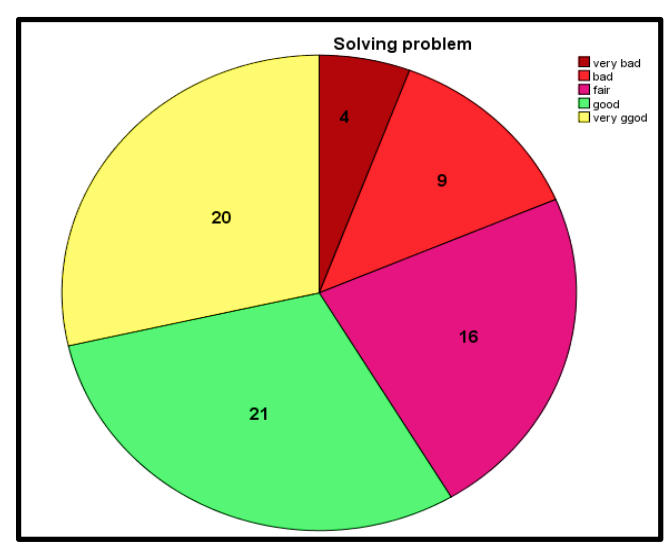

Figure 6 Using quality control programs in the firms in solving problems.

Figure 5 show the opinion of the employees about the benefits of quality control. The employees think the quality control is beneficial for procedural problems' detection by $58 \%$. However, a three-fifths of the employee thing that the quality control has a good impact on problem solving as shown in figure 6 .

\subsection{Effect of Quality Control Programs to Developing the Firms and Providing Training and Supervision, and Appreciation the Outstanding Staff}

Allowing employees to introducing new ideas and practices for developing the company has a wide influence to increasing confidence in the firm, and providing training and supervision for staff in performing their roles, and appreciation the outstanding staff, and his role to developing the firms are showing in figures 7, 8, 9 respectively.
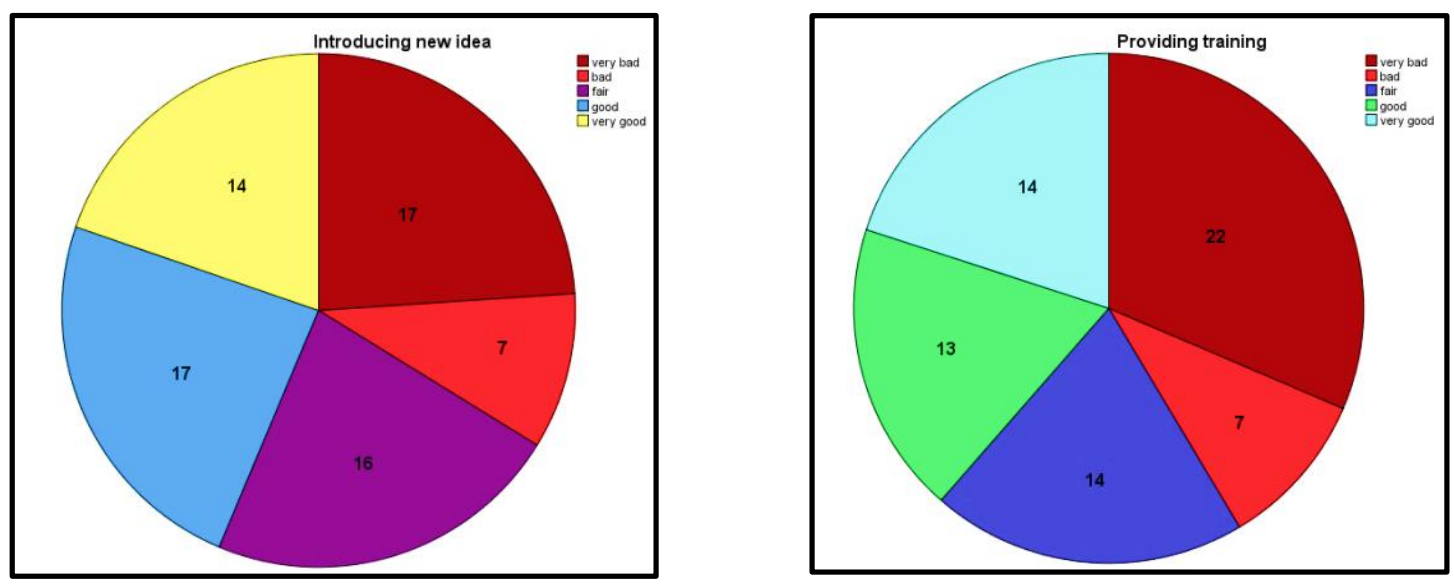

Figure 7 Introducing new ideas and practices Figure 8 Provide training and supervision for staff for developing the firms. 


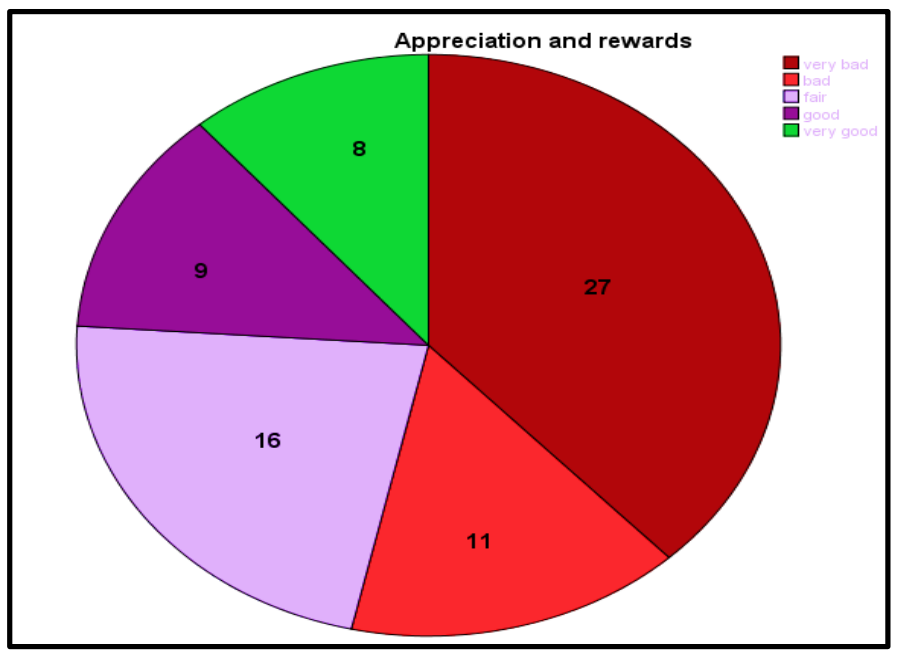

Figure 9 Appreciation and rewards in the firms

As illustrated in Figures 7, and 8 using of quality control is useful for the cement plants in proportion of $43 \%$, and $38 \%$ for introducing new ideas, and provide training respectively. While in relate to sage of appreciation and rewards, just under quarter of the employee believe that the quality control has a good influence on it in the firm.

\subsection{Effect of Quality Control to Increasing Roductivity and Profitability}

The effectiveness of quality control programs on productivity and profitability, and his influence to increasing productivity and profitability, and specifics was show in figures 10, and 11 respectively.
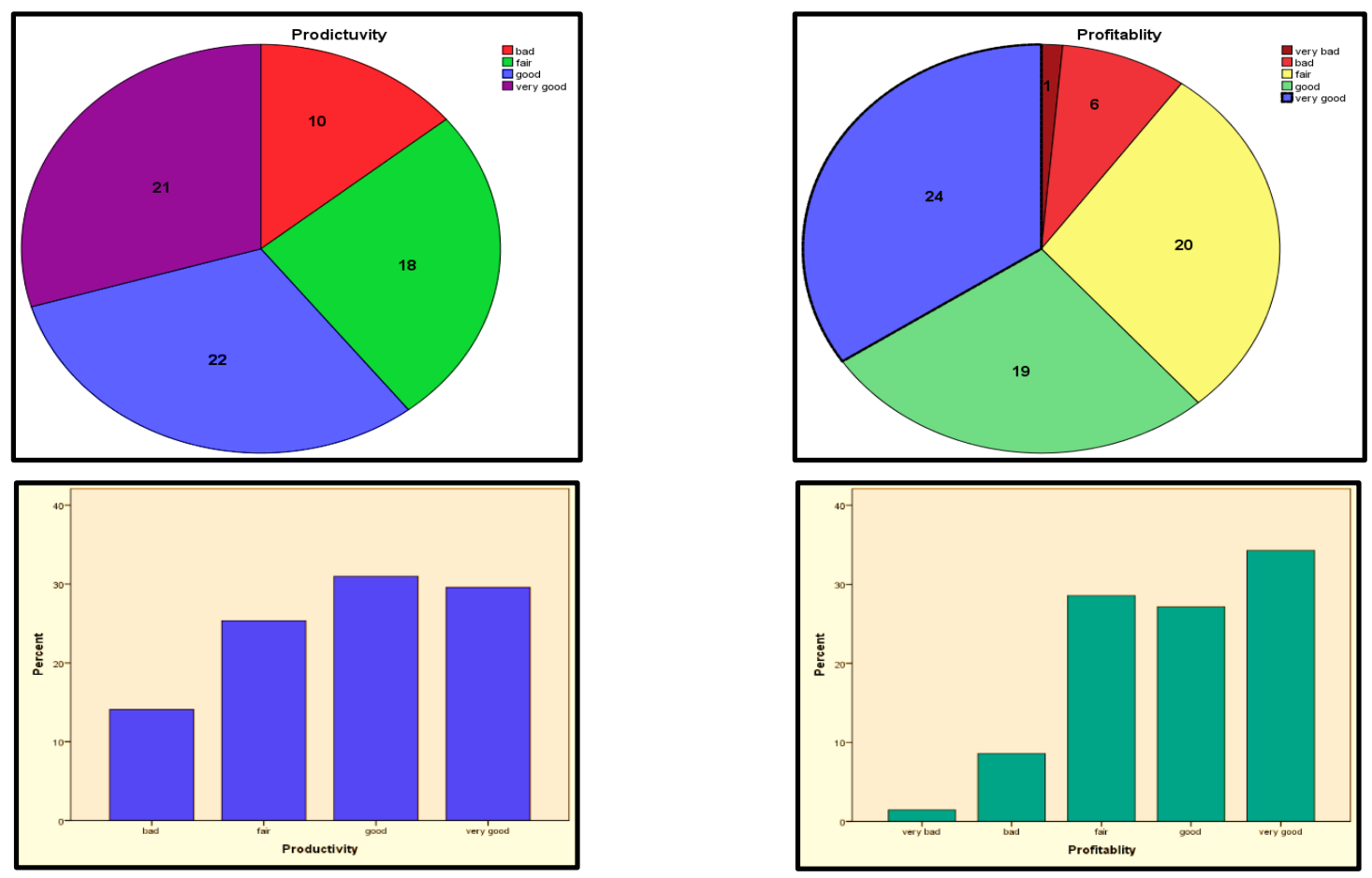

Figure 10 Role of quality control to increasing productivity Figure 11 Role of quality control to increasing. profitability

As detailed in figure 11, about three-fifths of employers considers that the quality control has a great impact on productivity and profitability in the cement factory, and it is a good result to indicate the effect of quality control. Every factory concentrate its attention and 
efforts to achieve high production rate and more profit, thus it must be noted that the good quality control leads them to achieve their goal successfully.

\section{CONCLUSIONS}

From this study, the following points can be concluded

- More than two of thirds of employer that believe to the quality control has an actual benefit in cement plants.

- Around half of employers that believe to the quality control has an important role to reducing risk, and think that the quality control program has an important role to losing time. This is indicates a lack of awareness about the quality control in cement plants.

- Less than half of employers in the cement factories consider that the quality control program has an improvement impact to improving the communication between them, and working together as a team. That is referring to scarcity of awareness on the quality control.

- Near $60 \%$ percentage of employers think that the implementation of quality control program to highlighting the problems and clear role to solving. Hence, it is clear the gap between senior management and workers in cement plants.

- Around $40 \%$ percentage of participations in questionnaire see the using of quality control program are useful in the cement plants to introducing new ideas, and provide training. While in relate to appreciation and rewards, just under quarter of the employee believe that the quality control has a good influence on it in the firm.

- With regard to the profitability, three-fifths of employers consider that the quality control has a major influence on productivity and profitability in the cement factory, and it is a good indicate to the influence of quality control programs.

\section{RECOMMENDATIONS}

Suggested Recommendations out of the study:

- Spreading awareness about quality control in the cement plants.

- Attention to teamwork, strengthening relations between workers and employers and breaking barriers.

- Making training courses for workers about quality control.

\section{REFERENCES}

[1] A. Alsughayir, "The Impact of Quality Practices on Productivity and Profitability in the Saudi Arabian Dried Date Industry," American Journal of Business and Management, 2013, Vol. 2, pp. 340-346.

[2] A. Agus A., et al., "An Empirical Investigation on the Impact of Quality Management on Productivity and Profitability: Associations and Mediating Effects," Contemporary Management Research, 2009, Vol. 5, pp. 77-92.

[3] M.P. Groover, "Automation, Production Systems, and Computer-Integrated Manufacturing," Publisher: Pearson education limited, London, $4^{\text {th }}$ Edition, 2014.

[4] H.D. Gatanas, "Leadership and Total Quality Management," United States Army., U.S. Army War College Carlisle, 1992.

[5] M. Alharbi, et al., "Leadership Styles, And Their Relationship with Quality Management Practices in Public Hospitals In Saudi Arabia," International Journal of Economics and Management Sciences, 2012, Vol. 1, pp. 59-67.

[6] J. R. Evans, et al., "The Management and Control of Quality," Thomson South-Western, 2007. 
[7] B.M. Bass, "Leadership and performance beyond expectations. New York" ,Free Press New York, 1985.

[8] D. A.Waldman, "The contributions of total quality management to a theory of work performance", Academy of Management Review, Vol. 19, pp. 510-536, 1994.

[9] T. Laohavichien, et al., "The effects of transformational and transactional leadership on quality improvement," Quality Management Journal, 2009, Vol. 16, pp. 7-24.

[10] U. M. Taslim, et al., "Productivity and Profitability Analysis of Eastern Refinery Limited (ERL) - An Evaluative Study," European Journal of Business and Management, 2014, Vol. 6, pp. 316-333.

[11] A. Smith, "An Inquiry into the Nature and Causes of the Wealth of Nations,"Edited with an introduction, notes, marginal summary and an enlarged index by Edwin Cannan, London: Methuen, 1904), 2019, Vol 1. 9/23/.

[12] D. Ricardo, "On the Principles of Political Economy and Taxation," Printed and bound by Edwards Brothers, Inc., Ann Arbor, Michigan, Volume 1, 2004.

[13] G. J. Stigler, “The Theory of Price,” USA, University of Chicago, Fourth Edition, 1966.

[14] E. W. Anderson, et al., "Customer Satisfaction, Productivity, and Profitability: Differences between Goods and Services," Marketing Science, 1997, Vol. 16, pp. 129145.

[15] Ha. A. Strappazzon L., et al., "Whats is the difference between productivity and profit," Economics Branch, Agriculture Division, Department of Natural Resources and Environment, Victoria, November 2001.

[16] A. Stierwald, "Determinants of Firm Profitability -The Effect of Productivity and its Persistence"., Melbourne Institute of Applied Economic and Social Research, University of Melbourne, June 2009.

[17] A. Agus A., "A linear structural modelling of Total Quality Management practices in manufacturing companies in Malaysia," Total quality management Journal, Graduate School of Business, UKM, Malaysia, 2001, Vol. 12, pp. 561-573.

[18] J. H. Khan, "Impact of total quality management on productivity," The TQM Magazine, 2003, Vol. 15, pp. 374-380.

[19] R. Selladurai, "An organizational profitability, productivity, performance (PPP) model: Going beyond TQM and BPR," Journal of Total Quality Management, 2010, Vol. 13, pp. 613- 619.

[20] W. E. Deming, "Out of the Crisis. Cambridge," MIT Press edition, Cambridge, Massachusetts, London, England, 2000.

[21] N. Al-Ansari, et al., "Climate change and future long-term trends of rainfall of north-west of Iraq," USA, Journal of Civil Engineering and Architecture, 2014, Vol. 8, pp. 790-805.

[22] Gasin Cement Company, "https:// www. Gasin Cement Company," 2019.

[23] Bazian and Tasluja Cement, IraqCom website, Iraq, Kurdstan Region, Sulaimaniyah, 2019. https://iraqcom.com/portfolio/bazian-and-tasluja-cement

[24] Mass Group Holding Website, Iraq, Kurdstan Region, Bazian, Kirkuk Sulaimaniyah main road, 2019. http://www.mass group holding

[25] Delta Cement Plant, Iraq, Kurdstan Region, Bazian Kirkuk Sulaimaniyah main road, 2019.http://delta-cement.com/Default.aspx 